\title{
Nitrogen rates and sources and Guinea Negro yam in an Ultisol in Puerto Rico'
}

\author{
Reinaldo del Valle-Gonzálezz and Miguel Santiago-Córdovas
}

\begin{abstract}
An experiment to study the effect of several rates and sources of $\mathrm{N}$ on the yield of Guinea Negro yam ( $D$. rotundafa) was planted in a Corozal clay (Aquic Tropodults) at the Corozal Substation in the humid region of Puerto Rico. The experiment consisted of 10 treatments replicated five times in a partially balanced incomplete block design. Treatments included sulphur-coated urea (SCU $36 \% \mathrm{~N}$ ), ammonium sulphate $(20.5 \% \mathrm{~N}$ ) and urea $(46 \% \mathrm{~N})$ as the $\mathrm{N}$ sources at 224,336 and $448 \mathrm{~kg} / \mathrm{ha}$. All plots except the control received 49,372 , and $90 \mathrm{~kg} / \mathrm{ha}$ of $\mathrm{P}, \mathrm{K}$, and $\mathrm{Mg}$, respectively, 2 and 5 months after planting. No significant differences were observed among treatments. An average of $46.24 \mathrm{t} / \mathrm{ha}$ was recorded, a yield which is considered good. Data from this study indicate that under the existing conditions, there was no need to apply different $\mathrm{N}$ sources and quantities. This soil initially has sufficient quantities of available nutrients for good yam production.
\end{abstract}

\section{RESUMEN}

Fuentes $\mathrm{y}$ dosis de nitrógeno y el ñame ( $D$. rotundata) en un Ultisol en Puerto Rico

Se hizo un experimento en un Ultisol (Aquic Tropodults) de Corozal para medir el efecto de varias fuentes de nitrógeno en el rendimiento del ñame cv. Guinea Negro. El experimento consistió de 10 tratamientos y cinco repeticiones distribuidas en un diseño parcialmente balanceado de bloques incompletos. Las fuentes de $\mathbf{N}$ fueron urea cubierta de azufre (SCU, $36 \% \mathrm{~N})$, sulfato amónico $(20.5 \% \mathrm{~N})$ y urea $(46 \% \mathrm{~N})$ aplicados a razón de 224,336 y $448 \mathrm{~kg}$./ha. Todas las parcelas excepto el control recibieron 49 , 372 y $90 \mathrm{~kg}$./ha. de $\mathrm{P}, \mathrm{K}$ y $\mathrm{Mg}$ aplicados dos y cinco meses después de la siembra.

Los resultados revelaron que no hubo diferencias significativas entre los tratamientos. Se obtuvo un rendimiento comercial medio de $46.24 \mathrm{tm}$. I ha. Los datos obtenidos de este estudio indican que bajo las condiciones en que se realizó el trabajo, no hubo ningún beneficio al utilizar distintas fuentes y cantidades de $N$, y sugiere que este suelo posee suficientes cantidades de nutrimentos para una buena producción comercial de ñames.

\section{INTRODUCTION}

Yams (Dioscorea spp.), a starchy food source in the tropics $(5,13,16)$, constitute the third most important farinaceous crop in Puerto Rico $(6,7)$. Total production in the island during $1985-86$ was 265,000 hundredweight

\footnotetext{
'Manuscript submitted to Editorial Board 2 February 1989.

${ }^{2}$ Associate Agronomist, Department of Agronomy and Soils

${ }^{3}$ Research Assistant, Department of Horticulture.
} 
with a farm value of $\$ 5.65$ million and a mean value of $\$ 21.32$ per hundredweight (7). The fresh tubers can provide approximately $500 \mathrm{cal} / 100 \mathrm{~g}$ of dry pulp, contain $3 \%$ protein and limited amounts of minerals (13). The per capita consumption in the island in 1985-86 was approximately 8.80 lb. (6) Yams are usually eaten boiled but can also be baked, sliced and fried. (13)

Yams are a staple food for much of West Africa, Oceania, the Caribbean Region, and parts of Asia (16). They are grown in West Africa under shifting cultivation or as the first crop in rotations in recently cleared forest areas and generally heavily intercropped. $(15,16)$

It has been argued that many tropical crops, including yam, have been selected to yield at low levels of nutrition and are relatively unresponsive to fertilizer applications. (15) Martin (14) states that considerable controversy exists with respect to the fertilization of $D$. alata. Data obtained from experiments with mineral fertilizers have often been misleading. Even reduced yields have been reported in response to fertilization. Juvenile plants apparently rely on nutrients stored in the vegetative "seed," even though significant $N$ supply is needed. Potassium also is needed at tuberization. (14) In addition, Martin summarizes the fertilizer recommendation of several workers as follows: Nigeria, 12-12-18, $60 \mathrm{~g}$ per plant (5); Trinidad, nitrogen $100 \mathrm{~kg} / \mathrm{ha}$ applied three months after planting; (12) Dominica, 3-9-18, $30 \mathrm{~g} /$ plant 4 to 6 weeks after planting; Barbados, ammonium sulfate and muriate of potash, $200 \mathrm{~kg}$ of each/ha. (11) Ferguson and Haynes, (8) in a review of N-P-K fertilizer research with this crop, point out that most research on fertilizer used for yam has shown 10 to $20 \%$ increase in tuber yield with nitrogen applications. No consistent response to phosphate fertilizers has been observed, whereas in general, yams have responded to low levels of potassium.

In Puerto Rico, where yam is generally grown as a monocrop, there has been only limited research on its nutritional requirements. Gaztambide and Cibes (10) studying yam nutrient deficiencies in sand culture, reported that lack of N, P, K, Ca and S significantly curtailed growth and tuber yield. Plants lacking potassium showed the most marked foliar symptoms. Irizarry and Rivera (13) studied yam nutrient uptake and dry matter production on a Corozal clay soil (a Ultisol). Their results indicated that to obtain optimum yields it was necessary to apply 224, 68, 258 and $56 \mathrm{~kg} / \mathrm{ha}$ of $\mathrm{N}, \mathrm{P}_{2} \mathrm{O}_{5}, \mathrm{~K}_{2} \mathrm{O}$ and $\mathrm{MgO}$, respectively. This would be equivalent to $2,000 \mathrm{~kg} / \mathrm{ha}$ of a 14-3-13-3 commercial fertilizer formulation. It was recommended that the fertilizer be applied in equal increments at 2 and 5 months after planting. Acevedo-Borrero, (3) when studying the effect of $\mathrm{P}$ and $\mathrm{K}$ levels on the yield of yam in a Coto soil (an Oxisol) at Isabela, obtained a highly significant linear response to $\mathrm{P}_{2} \mathrm{O}_{5}(0,34,68$, 102 and $136 \mathrm{~kg} / \mathrm{ha})$ and $\mathrm{K}_{2} \mathrm{O}(0,129,258,358$, and $516 \mathrm{~kg} / \mathrm{ha})$. No signif- 
icant $\mathrm{P}_{2} \mathrm{O}_{5}-\mathrm{K}_{2} \mathrm{O}$ interactions were observed. The author concluded that for a Coto soil deficient in $\mathrm{P}(4 \mathrm{p} / \mathrm{m})$ and $\mathrm{K}(46 \mathrm{p} / \mathrm{m})$, yams should be fertilized with $1,700 \mathrm{~kg} / \mathrm{ha}$ of a $12-2-10$ fertilizer with microelements. An average yield of $44.8 \mathrm{t} / \mathrm{ha}$ was recorded. Other yam studies on the same Coto series indicated high yields without significant $\mathrm{N}, \mathrm{P}$ and $\mathrm{K}$ differences, but suggested a possible effect of $\mathrm{N}$ sources (4).

The objective of the present study was to determine the effect of three levels of three $N$ sources on yam yield on an Ultisol soil in the humid upland region of Puerto Rico.

\section{MATERIALS AND METHODS}

The work was performed at the AEis-UPR Corozal Substation. The soil series is a Corozal clay (Aquic Tropudults), $\mathrm{pH} 4.76$, containing 6.1, 317,1558 and $196 \mathrm{p} / \mathrm{m}$ of $\mathrm{P}, \mathrm{K}, \mathrm{Ca}$ and $\mathrm{Mg}$, respectively. Total $\mathrm{N}$ was 0.15 percent.

The site was plowed and disc-harrowed three times. About 3.7 tons/ha of crushed limestone was incorporated into the soil before planting. Seed pieces of yam cultivar Guinea Negro, each weighing $168 \mathrm{~g}(6 \mathrm{oz}$.), were planted $0.30 \mathrm{~m}$ apart in four ridged rows spaced at $1.37 \mathrm{~m}$. Rows were $4.57 \mathrm{~m}$ long. Vines were supported by $1.5-\mathrm{m}$ long wooden stakes.

Controlled variables consisted of 10 treatments replicated five times in a partially-balanced incomplete block design. Each plot received a total of 49,372 , and $90 \mathrm{~kg} / \mathrm{ha}$ of $\mathrm{P}, \mathrm{K}$ and $\mathrm{Mg}$, respectively, applied in two equal applications at 2 and 5 months after planting. Sulphur-coated area (SCU $36 \% \mathrm{~N})$, ammonium sulphate $(20.5 \% \mathrm{~N})$, and urea $(46 \% \mathrm{~N})$ were used as the variable $N$ sources. They were mixed with $P, K$, and $\mathrm{Mg}$ in complete formulations. The SCU was applied only once, 2 months after planting.

Weeds were controlled by a pre-emergence Ametryn, ${ }^{3}$ [2-(ethylamino)-4- isopropylamino-6-(methylthio)-s-triazine] application at the rate of 2.24 (a.i.) $\mathrm{kg} / \mathrm{ha}$ and later by handweeding. Nematodes and soil insects were controlled with an application of Temik 10G [2-methyl-2(methyl-thio) propionaldehyde 0-methyl-carbomyl oximel] at $47 \mathrm{~kg} / \mathrm{ha}$. As a preventive to control possible "leaf spot" disease, 4 months after planting we applied Benlate (methyl-butyl-carbamyol)-2- benzimidazole carbomate) at the rate of $1.37 \mathrm{~kg} / \mathrm{ha}$ in $454 \mathrm{~L}$ of water. Supplementary irrigation was administered as needed during dry spells. The experiment was harvested at nine months; all plants were used for yield calculations.

\footnotetext{
'Thade names in this publication are used only to provide specific information. Mention of a trade name does not constitute a warranty of equipment on materials by the AES-UPR, nor is the mention a statement of preference over other equipment on materials.
} 
TABLE 1.-Fertilizer treatment levels ond effect of nitrogen sources on the yield of Gninea Negro yom at Corozal-April, 1984-February, 1985

\begin{tabular}{lccccr}
\hline & \multicolumn{5}{c}{$\mathrm{kg} / \mathrm{ha}$} \\
\cline { 2 - 6 } \multicolumn{1}{c}{ Treatment } & $\mathrm{N}$ & $\mathrm{P}$ & $\mathrm{K}$ & $\mathrm{Mg}$ & $\mathrm{mt} / \mathrm{ha}$ \\
\hline 1. Control & 0 & 0 & 0 & 0 & 45.00 \\
2. S. C. U.' $(36 \% \mathrm{~N})$ & 224 & 49 & 372 & 90 & 49.46 \\
3. S. C. U. $(36 \% \mathrm{~N})$ & 336 & 49 & 372 & 90 & 45.00 \\
4. S. C. U. $(36 \% \mathrm{~N})$ & 448 & 49 & 372 & 90 & 47.90 \\
5. A.S. $(20.5 \% \mathrm{~N})$ & 224 & 49 & 372 & 90 & 45.23 \\
6. A. S. $(20.5 \% \mathrm{~N})$ & 336 & 49 & 372 & 90 & 47.00 \\
7. A.S. $(20.5 \% \mathrm{~N})$ & 448 & 49 & 372 & 90 & 47.90 \\
8. Urea $(46 \% \mathrm{~N})$ & 224 & 49 & 372 & 90 & 43.92 \\
9. Urea $(46 \% \mathrm{~N})$ & 336 & 49 & 372 & 90 & 46.78 \\
10. Urea $(46 \% \mathrm{~N})$ & 448 & 49 & 372 & 90 & 44.17 \\
\hline 'Yield. & & & & & ave. 46.24 \\
2Ammonium sulphate. & & & & & c.v. $13.0 \%$
\end{tabular}

\section{RESULTS AND DISCUSSION}

Yields of marketable tubers ranged from 49.46 to $43.92 \mathrm{t} / \mathrm{ha}$ (table 1 and fig. 1). The mean yield of $46.24 \mathrm{t} / \mathrm{ha}$ is considered good. Plots without fertilizer produced $45.00 \mathrm{t} / \mathrm{ha}$, essentially equaling the yields of other treatments. A slightly higher yield of $51.6 \mathrm{t} / \mathrm{ha}$ of marketable tubers was obtained by Irizarry and Rivera (13) from the same (Ultisol) soil at Corozal in January 1985.

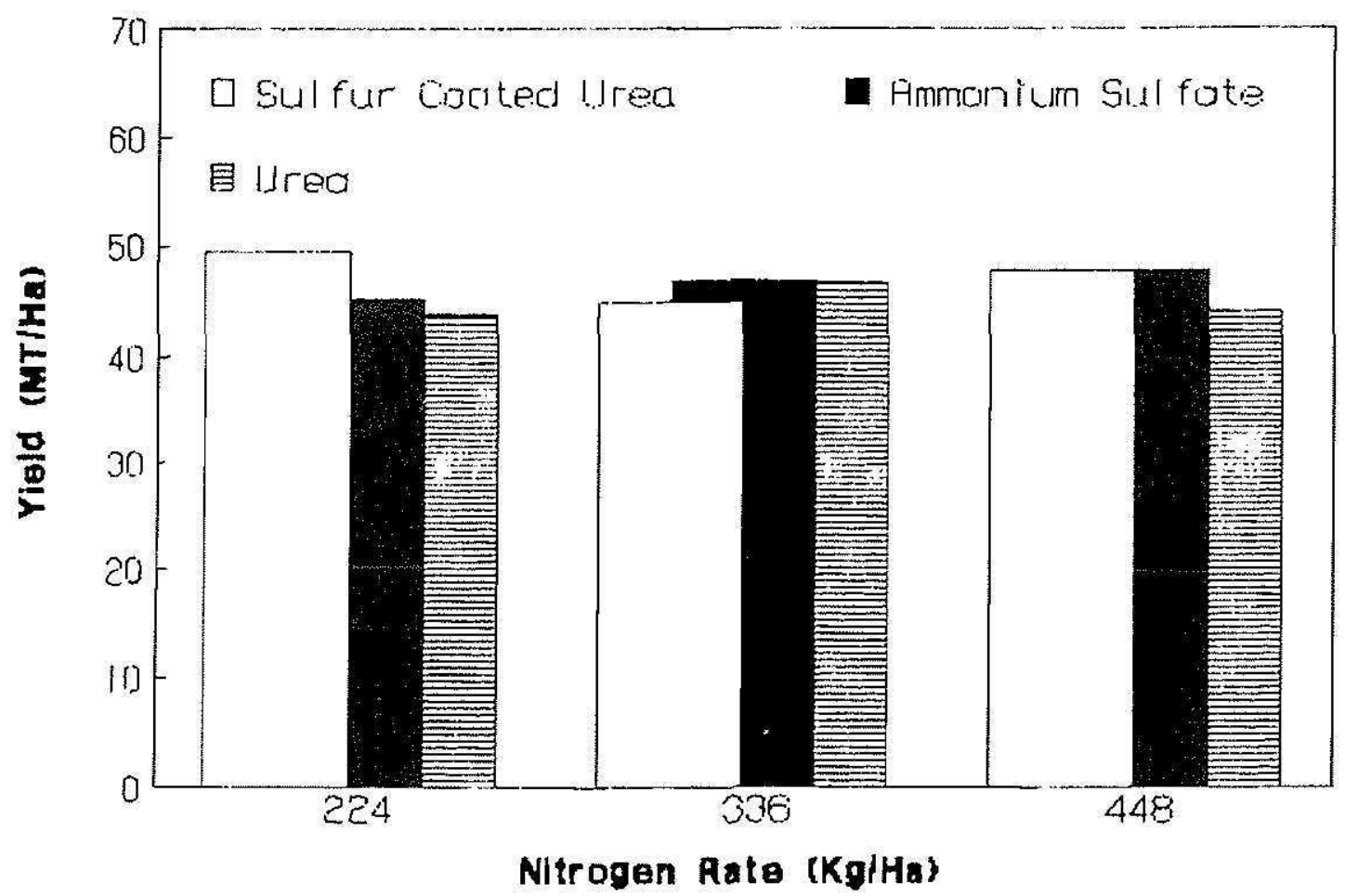

FIG. 1-Effect of $\mathrm{N}$ sources and rates on the yield of Guinea Negro yam. 
TABLE 2.-Nutrient content in the soil at Corozal before planting and after harvesting yam $N$ sources experiment, April 1985

\begin{tabular}{|c|c|c|c|c|c|c|c|c|c|c|c|c|}
\hline \multirow[b]{2}{*}{ Treatments } & \multicolumn{2}{|c|}{$\mathrm{pH}$} & \multicolumn{2}{|c|}{$\mathrm{P}$} & \multicolumn{2}{|c|}{$\mathrm{K}$} & \multicolumn{2}{|c|}{$\mathrm{Ca}$} & \multicolumn{2}{|c|}{$\mathrm{Mg}$} & \multicolumn{2}{|c|}{$\%$ Total N } \\
\hline & $a^{\prime}$ & $b=$ & a & b & a & $\mathrm{b}$ & a & b & a & b & a & b \\
\hline 1. Control & 4.78 & 5.26 & 7.4 & 8.2 & 316 & 267 & 1572 & 1494 & 193 & 165 & 0.15 & 0.20 \\
\hline 2. Sulphur coated urea $(36 \% \mathrm{~N})$ & 4.72 & 5.13 & 4.0 & 9.4 & 298 & 219 & 1527 & 1379 & 195 & 175 & 0.13 & 0.16 \\
\hline 3. Sulphur coated urea $(36 \% N)$ & 5.08 & 5.13 & 10.8 & 12.8 & 376 & 313 & 1750 & 2172 & 218 & 225 & 0.15 & 0.18 \\
\hline 4. Sulphur coated urea $(36 \%$ N) & 4.68 & 4.78 & 6.6 & 6.2 & 307 & 209 & 1536 & 1291 & 176 & 146 & 0.13 & 0.15 \\
\hline 5. Ammonium sulphate $(20.5 \% \mathrm{~N})$ & 4.62 & 4.80 & 5.0 & 10.6 & 315 & 223 & 1442 & 1364 & 183 & 155 & 0.12 & 0.16 \\
\hline 6. Ammonium sulphate $(20.5 \% \mathrm{~N})$ & 4.86 & 5.02 & 7.2 & 10.4 & 319 & 256 & 1753 & 1606 & 237 & 208 & 0.13 & 0.18 \\
\hline 7. Ammonium sulphate $(20.5 \% \mathrm{~N})$ & 5.02 & 5.02 & 7.0 & 18.4 & 270 & 243 & 1859 & 1687 & 245 & 214 & 0.12 & 0.18 \\
\hline 8. Urea $(46 \% N)$ & 4.64 & 5.60 & 6.8 & 8.0 & 315 & 232 & 1401 & 1142 & 172 & 124 & 0.12 & 0.17 \\
\hline 9. Urea $(46 \% \mathrm{~N})$ & 4.55 & 4.45 & 2.0 & 6.8 & 296 & 265 & 1362 & 1215 & 172 & 149 & 0.12 & 0.16 \\
\hline 10. Urea $(46 \% \mathrm{~N})$ & 4.64 & 4.91 & 4.6 & 7.0 & 354 & 246 & 1380 & 1369 & 170 & 158 & 0.13 & 0.18 \\
\hline
\end{tabular}

'Before planting, in $\mathrm{p} / \mathrm{m}$.

${ }^{2}$ After harvesting, in $\mathrm{p} / \mathrm{m}$. 
The lack of response to $\mathrm{N}$ applications in this soil appears to be due to relatively high $\mathrm{N}$-supplying capacity of Ultisols (9). Experiments with tropical grasses $(1,17)$ on Ultisol and Oxisol soils indicated that their nutrient supplying ability was about $80 \mathrm{~kg} /$ ha yearly for both $\mathrm{N}$ and $\mathrm{K}_{2} \mathrm{O}$. In another experiment with stargrass, the efficiency of various sulphurcoated urea (SCU) and $\mathrm{KCl}$ was compared to the efficacy of the uncoated materials in an Ultisol (Humatas clay) at Orocovis, the findings revealed that the use of nitrogen as urea in six applications yearly, or one single yearly application of several SCU compounds resulted in a greater recovery of fertilizer $\mathrm{N}$ in the forage than the use of urea in one single yearly application. (2) However, since results obtained in this experiment showed no response to $\mathrm{N}$ levels, neither would $\mathrm{N}$ source be expected to have any effect on yields.

Nutrient contents of the present soil site, before and after harvest are presented in table 2. Soil samples taken at a $20-\mathrm{cm}$ depth before planting revealed low amounts of P, ranging from 2 to $10.8 \mathrm{p} / \mathrm{m}$. Slightly higher contents were observed after harvesting the experiment (increased from 6.2 to 18.4). However, no yield response to this nutrient was obtained, nor were deficiencies observed. Calcium was moderately high at both sampling times. $\mathrm{K}$ and $\mathrm{Mg}$, although lower than $\mathrm{Ca}$, were present in sufficient amounts.

Data from this study indicate that under the existing conditions, there was no need to apply different sources and quantities of $\mathrm{N}$, and suggest that this soil initially has sufficient quantities of available nutrients for good commercial yam production. However, with continued intensive production, a maintenance fertilizer program coupled with well-planned commodity rotations, will be necessary. The $\mathrm{N}$ source to be used must take into account both cost and soil-acidifying.

\section{LITERATURE CITED}

1. Abruña, F., J. Vicente-Chandler, J. Figarella and S. Silva, 1976. Potassium supplying power of the major Ultisols and Oxisols of Puerto Rico. J. Agric. Univ. P. R. 60 (1): 45-60.

2. —, J. Figarella and R. Caro-Costas, 1976. Efficiencyof sulfur coated urea and potassium chloride compounds applied to stargrass growing in an Ultisol under humid tropical conditions. J. Agric. Univ. P. R. 60 (3): 310-15.

3. Acevedo-Borrero, E., 1988. The effect of $P$ and $K$ levels on the yield of yam $(D$. rolundata Poir) intensively managed in an Oxisol. M.S. Thesis, Univ. P. R. Mayagüez, P. R.

4. Barahona-Martínez, R., 1976. Efecto de tratamientos variables de fertilización en la composición química de los tejidos aéreos y de la raíz tuberosa en el name de Guinea en un Oxisol (Coto arcilloso). Tesis presentada en complimiento parcial para el grado de Maestría en Ciencias, Universidad de Puerto Rico, Mayagüez, P. R.

5. Coursey, D. G., 1967. Yams. An account of the nature, origins, cultivation of the useful members of the Discoreaceae. Longmans, London.

6. Departamento de Agricultura de Puerto Rico. 1986. Consumo de Alimentos en Puerto Rico. 
7. - 1985-86. Ingreso Bruto Agricola de P. R.

8. Ferguson, T. U. and P. H. Haynes, 1970. The response of yams, (Dioscorea spp.) to nitrogen, phosphorus, potassium and organic fertilizer': Proc. Second Symposium on root and tuber crops. Hawaii, Vol. I, pp. 93-6.

9. Fox, R. H., H. Talleyrand and D. R. Boulding, 1974. Nitrogen fertilization of corn and sorghum grown in Oxisols and Ultisols in Puerto Rico. Agron. J. 66: 534-40.

10. Gaztambide, S. and R. Cibes, 1975. Nutritional deficiencies of yams (Dioscorea spp.) and related effects on yield and leaf composition. J. Agric. Univ. P. R. 59 (4): 264-73.

11. Gooding, E. G. B., 1971. Effects of fertilizing and other factors on yams in Barbados. Exp. Agric. 7: 315-19.

12. Haynes, P. H. and D. G. Coursey, 1969. Gigantism in the yam. Trop. Sci. 11 (2): 93-6.

13. Irizarry, $H$. and $E$. Rivera, 1985 . Nutrient uptake and dry matter production by intensively managed yams grown in an Ultisol. J. Agric. Univ. P. R. 65 (1): 1-9.

14. Martin, W., 1976. Tropical yams and their potential. Part. 3. Dioscorea alata. Agric. Handb. 495, Agricultural Research Service, U.S.D.A., pp. 1-39.

15. Russel, E. W.. 1968. The place of fertilizers in food crop agronomy of Tropical Africa. Proc. Fert. Soc., London 101.

16. Vander Zaag, P., R. H. Fox, P. K. Kwakye and G. O. Obigbesan, 1980. The phosphorus requirements of yams. Trop. Agric. (Trinidad) 57 (2): 97-106.

17. Vicente-Chandler, J., F. Abruña, R. Caro-Costas, J. Figarella, S. Silva and R. W. Pearson, 1974. Intensive grassland management in the humid tropics of Puerto Rico, Agric. Exp. Stn. Univ. P. R. Bull, 233. 